\title{
PENILAIAN KINERJA EMBUNG HALIWEN BERDASARKAN KRITERIA PEMELIHARAAN EMBUNG IRIGASI
}

\author{
Melchior Bria', Sutirto ${ }^{2}$, Anastasia H. Muda ${ }^{3}$. \\ 1,2,3 Jurusan Teknik Sipil, Politeknik Negeri Kupang (PNK) \\ Email: ${ }^{1}$ melchibria@yahoo.co.id
}

\begin{abstract}
This research aims to determine how high the level of effectiveness, how the level of service and how the satisfaction of Pedestrian Bridge (PB) users in the Market Kramat Jati. Observations were made by calculating the volume of crossers using and not using the $P B$ as well as the volume of vehicles passing during the morning rush hour and afternoon peak hours both on weekdays and on holidays. This data is used as the basis for the analysis of the effectiveness and determination of the appropriate type of crossing facilities. The observation of the user time of $\mathrm{PB}$ with the sample of 29 people for each observation time. Data collection also used questionnaires to $53 \mathrm{~PB}$ user respondents containing questions relating to the physical components of $P B$ and supporting data that became the basic variables of consideration for the use of PB. The effectiveness analysis result shows that the JPO is not effective at the service level including category A. Based on the user satisfaction analysis, $59 \%$ are satisfied and very satisfied using the $P B$ with the age range of 2130 years old, the high school education, the most self employed, the monthly income $1-3$ million, the frequency of work usage $<2 x$ per day, from destination to shopping / market with the intention to work.
\end{abstract}

Keywords: Effectiveness, Pedestrian Bridge, User Satisfaction, Level Of Service.

\begin{abstract}
ABSTRAK
Embung Haliwen merupakan salah satu Embung Irigasi andalan di Kabupaten Belu dan melayani masyarakat Desa Sirani untuk keperluan irigasi untuk tanaman pengolahan tanaman padi. Untuk itu perlu dipertahankan keberlanjutannya sehingga dapat memberikan manfaat bagi masyarakat sekitar. Penelitian ini dimaksudkan untuk menilai kinerja embung Haliwen berdasarkan Kriteria Pemeliharaan Embung Irigasi. Penilain dilakukan dengan cara emberi bobot pada kriteria, kemudian dari nilai bobot tersebut dirata-rata untuk mendapatkan bobot keseluruhan. Adapun kriteria yang dimaksud adalah Stabilitas Struktur, Kriteria Fisik dan Lingkungan, Kriteria Eknomi/Fnansial, Kriteria Kebijakan Pemerintah, dan Kriteria Sosial Budaya. Hasil penelitian menunjukkan bahwa rata-rata nilai kinerja Embung Haliwen ada pada kisaran 3,41, sehingga dapat dikatakan dalam kategori Cukup. Hal ini berarti kinerja embung irigasi Haliwen perlu ditingkatkan lagi guna menjamin keberlanjutan system irigasi menggunakan air adri embung Haliwen.
\end{abstract}

Kata Kunci : Kinerja, Embung, Irigasi, Pemeliharaan

\section{PENDAHULUAN}

Permasalahan embung (small farm water reservoir) irigasi pada umumnya adalah degradasi fungsional, ditandai dengan berkurangnya kapasitas air tertampung, sedimentasi, rembesan, tumbuhnya tanaman liar pada tubuh bendung/tanggul, erosi, dan beberapa masalah lainnya, (Kasiro, 1995; Aditya, 2012.) Notoatmojo dkk (2001) dalam suatu survey di Nusa Tenggara Timur menemukan nilai efisiensi sistem embung irigasi $67 \%$ berdasarkan pada perbandingan antar nilai penyaluran air dengan nilai pemakaian air. Terkait hal ini Hermantoro (2011) mengemukaan bahwa efektivitas embung sebagai cadangan air di musim kemarau sangat tergantung pada besarnya nilai kehilangan air melalui evaporasi, rembesan samping dan perkolasi.

Embung Haliwen di Kabupaten Belu, menunjukkan adanya kehilangan air yang cukup besar, sekitar 30\% volume tampungan normal. Embung ini Secara topografi, berada pada ketinggian sekitar 340 meter dari permukaan laut dilihat dari puncak tanggul dan berada dalam pola aliran air sehingga memungkinkan air 
dengan mudah terperangkap dalam kolam (storage) embung. Embung Haliwen didisain sebagai embung homogen dan bertipe zonal dimana tubuh embung utama adalah zona inti dan dilindungi dengan urutan bolder yang juga adalah zona transisi dan urugan batu bagian luarnya. Mercu embung pada ketinggian 340 meter dengan kemiringan lereng udik sebesar $1.00: 2.50$ dengan ketebaln rip-rap 0, 50 meter dari batu berdiameter $10 \mathrm{~s} / \mathrm{d} 20 \mathrm{~cm}$. Sedangkan kemiringan lereng hilir $1.00 \mathrm{~V}$ : $2.00 \mathrm{H}$ didesain ulang dengan kemiringan lereng udik $1.00 \mathrm{~V}: 3.00 \mathrm{H}$ dan berm selebar 7.5 meter pada elevasi 330, (PPSA, 2003).

Untuk menjamin keberfungsian dan keamanannya (Ernanda, 2013; Aditya, 2012), embung terbangun dari beberapa komponen, yaitu: kolam embung, tubuh bendungan, bangunan (alat) sadap, pelimpah, pintu air, Jaringan distribusi air (retikulasi), dan bangunan bantu dan sangat dipengaruhi oleh aspek operasi dan pemeliharaan. Wiradnyana, 2013, menyatakan operasi embung/waduk adalah usaha-usaha memanfaatkan air yang tertampung pada tampungan efektif secara optimal. Sedangkan pemeliharaan embung/waduk adalah usaha-usaha untuk menjaga agar sarana prasarana yang ada selalu dapat berfungsi dengan baik, selama umur bangunan embung dan jangka waktu pelayanan yang direncanakan.

Kegiatan operasi mencakup aspek, rencana operasi jaringan irigasi, pelaksanaan operasi jaringan irigasi dan kegiatan operasi jaringan irigasi. Rencana operasi mencakup pola tanam dan tata tanam, kebutuhan air, ketersediaan air, dan pembagian air. Pelaksanaan operasi jaringan mencakup operasi pada musim hujan dan pada musim kemarau. Sedangkan kegiatan operasi jaringan meliputi pengumpulan data, kalibarasi pintu/alat ukur, penyuluhan, menyusun rencana tahunan penyediaan air, melaksanakan pembagian dan pemberian air (Kepmen PU No. 13/PRT/M/2012).
Ernanda (2013), pada penilaian aset irigasi yang dilaksanakan oleh pelaksana lapang (juru pengairan/pengamat) hanya berorientasi pada kerusakan dan ketidakberfungsian struktur bangunan irigasi, belum memadukan nilai kondisi/keberfungsian antar kompenen aset struktur, bangunan ukur dan pintu. Hal ini menyebabkan terjadinya perbedaan dalam penilaian sehingga penetapan prioritas menjadi bergeser.

Sedangkan kriteria-kriteria yang berpegaruh dalam perencanaan program pemeliharaan embung irigasi Haliwen dan Haekrit pada Tabel 1.

Tabel 1 Kriteria Pemeliharaan Embung Irigasi

\begin{tabular}{|c|c|}
\hline KRITERIA & SUBKRITERIA \\
\hline $\begin{array}{ll}\text { A. } & \text { STABILITAS } \\
& \text { STRUKTUR }\end{array}$ & $\begin{array}{l}\text { A1. Tubuh Bendungan } \\
\text { A2. Kolam Embung } \\
\text { A3. Spillway } \\
\text { A4. Bangunan Bantu } \\
\text { A5. Jaringan Distribusi } \\
\text { Air } \\
\text { A5. Nilai Kinerja }\end{array}$ \\
\hline $\begin{array}{ll}\text { B. } & \text { FISIK DAN } \\
& \text { LINGKUNGAN }\end{array}$ & $\begin{array}{l}\text { B1. Perubahan } \\
\text { Bentangan Alam } \\
\text { B2. Curah Hujan dan } \\
\text { Evapotranspirasi } \\
\text { B3. Struktur Tanah } \\
\text { sekitar Embung } \\
\text { B4. Tanaman } \\
\text { Pengganggu } \\
\text { Sekitar Embung }\end{array}$ \\
\hline $\begin{array}{l}\text { C. EKONOMI/ } \\
\text { FINANSIAL }\end{array}$ & $\begin{array}{l}\text { C1. Hasil Produksi } \\
\text { Pertanian } \\
\text { C2. Nilai manfaat } \\
\text { ekonomi embung } \\
\text { C3. Dana Investasi }\end{array}$ \\
\hline $\begin{array}{ll}\text { D. } & \text { KEBIJAKAN } \\
& \text { PEMERINTAH }\end{array}$ & $\begin{array}{l}\text { D1. Rencana Tata } \\
\text { Ruang Wilayah } \\
\text { D2. Penyediaan } \\
\text { Anggaran } \\
\text { Pemeliharaan } \\
\text { D3. Water Management } \\
\text { D4. Aspek } \\
\text { Kelembagaan } \\
\text { (Organisasi) }\end{array}$ \\
\hline $\begin{array}{ll}\text { E. } & \text { SOSIAL } \\
& \text { BUDAYA }\end{array}$ & $\begin{array}{ll}\text { E1. Partisipasi } \\
\text { Masyarakat } \\
\text { E2. Kearifan } \\
\text { Lokal/Hukum Adat } \\
\text { E3. Pengembangan } \\
\text { Kepariwisataan }\end{array}$ \\
\hline
\end{tabular}

Sumber : Bria, 2017 
Berdasarkan uraian di atas dan kriteriakriteria pada Tabel 1, maka permasalahan yang dibahas adalah bagaimana Kinerja embung Haliwen jika ditinjau dari kriteria dan subkriteria menurut petani pemakai air.

\section{BAHAN}

Penelitian ini merupakan penelitian survey dengan analisis deskriptif untuk menggambarkan kegiatan operasi dan pemeliharaan embung irigasi Haliwen. Adapun survey yang dimaksud adalah survey terhadap persepsi petani pemakai air di Sirani Desa Uma Klaran, Haliwen, Kabupaten Belu. terhadap kegiatan operasi dan pemeliharaan.

Survey menggunakan kuesioner dengan pertanyaan disusun sedemikian rupa sehingga responden dapat dengan mudah memahami dan memberi tanggapan sesuai yang diharapakan. Bobot penilaian menggunakan Skala Likert dimana :

a. Skor 5 untuk menyatakan tingkatan sangat Baik/Penting/Setuju

b. Skor 4 untuk menyatakan tingkatan Baik/Penting/Setuju

c. Skor 3 untuk menyatakan tingkatan cukup Baik/Penting/Setuju

d. Skor 2 untuk menyatakan tingkatan tidak Baik/Penting/Setuju

e. Skor 1 untuk menyatakan tingkatan sangat tidak Baik/Penting/Setuju

\section{METODA PENELITIAN}

Penilaian kinerja embung dalam penelitian ini dilakukan oleh Petani Pemakai Air berdasarkan Kriteria Pemeliharaan Embung Irigasi pada Tabel 1.. Sedangkan hasil penilaian terhadap kinerja embung ini ditabulasi untuk menentukan rata-rata dan skor akhir dari masing-masing kriteria. Sedangkan Bobot kinerja embung berdasarkan kriteria ditentukan dengan persamaan: $N=N K_{1}+N K_{2} \ldots \ldots \ldots \ldots+$ Dimana $\mathrm{NKn}=$ Nilai Bobot Kriteria ke $n$ Nrata - rata $=\frac{\text { Jumlah Nilai }}{\text { Jumlah Kriteria }}$

\section{HASIL DAN PEMBAHASAN}

Secara topografi, embung Haliwen berada pada ketinggian sekitar 340 meter dari permukaan laut dilihat dari puncak tanggul dan berada dalam pola aliran air sehingga memungkinkan air dengan mudah terperangkap dalam kolam (storage) embung. Data pada awal pembangunan menunjukkan bahwa embung Haliwen umumnya dibangun di atas batuan dasar berupa batu lempung hingga batu lempung kelanauan, pasiran, sisipan batu pasir, bersifat lunak dengan nilai kelulusan air yang tinggi antara $10^{-6} \mathrm{~s} / \mathrm{d} 10^{-5} \mathrm{~cm} /$ detik Embung Haliwen didisain sebagai embung homogen dan bertipe zonal dimana tubuh embung utama adalah zona inti dan dilindungi dengan urutan bolder yang juga adalah zona transisi dan urugan batu bagian luarnya. Mercu embung pada ketinggian 340 meter dengan kemiringan lereng udik sebesar $1.00: 2.50$ dengan ketebaln rip-rap 0,50 meter dari batu berdiameter $10 \mathrm{~s} / \mathrm{d} 20$ $\mathrm{cm}$. Sedangkan kemiringan lereng hilir $1.00 \mathrm{~V}: 2.00 \mathrm{H}$ didesain ulang dengan kemiringan lereng udik $1.00 \mathrm{~V}: 3.00 \mathrm{H}$ dan berm selebar 7.5 meter pada elevasi 330, (BWS NT II, 2003).

Saluran irigasi pada embung Haliwen berupa pasangan batu dengan panjang saluran hingga ke bangunan bagi adalah \pm 1500 meter. Kinerja saluran irigasi secara umum terlihat baik, dinding saluran utuh dan rapih, hanya saja pada 1 ruas setelah bangunan bagi sedikit mengalami pelepasan campuran plesteran pada saluran. Debit aliran air terukur sebesar 124,26 liter/detik.

Hasil Penilaian pada kriteria Stabilitas Struktur (Tabel 5) menunjukkan struktur embung terlihat cukup berfungsi. 
Tabel 5 Penjelasan Kriteria Stabilitas Struktur

\begin{tabular}{|c|c|}
\hline $\begin{array}{l}\text { Kriteria Stabilitas } \\
\text { Struktur }\end{array}$ & Pernyataan \\
\hline $\begin{array}{l}\text { A1. Tubuh } \\
\text { Bendungan }\end{array}$ & $\begin{array}{l}\text { Tidak terdapat Rembesan } \\
\text { pada tumbuh bendungan, } \\
\text { retakan melintang dan } \\
\text { memanjang, longsoran } \\
\text { lokal, retakan susut, dan } \\
\text { erosi alur }\end{array}$ \\
\hline $\begin{array}{ll}\text { A2. } & \text { Kolam } \\
\text { Embung }\end{array}$ & $\begin{array}{l}\text { Endapan lumpur masih } \\
\text { berada pada dead storage, } \\
\text { tidak ada kotoran atau } \\
\text { ranting pohon pada } \\
\text { kolam, pagar disekeliling } \\
\text { kolam baik, papan duga } \\
\text { berfungsi, pelampung } \\
\text { berfungsi }\end{array}$ \\
\hline A3. Spillway & $\begin{array}{l}\text { Tidak ada runtuhan di } \\
\text { saluran pelimpah, erosi } \\
\text { alur di saluran pelimpah, } \\
\text { gerusan lokal, sepanjang } \\
\text { pelimpah }\end{array}$ \\
\hline $\begin{array}{ll}\text { A4. } & \text { Bangunan } \\
\text { Bantu }\end{array}$ & Tersedia dan berfungsi \\
\hline $\begin{array}{ll}\text { A5. } & \text { Jaringan } \\
\text { Distribusi } \\
\text { Air }\end{array}$ & $\begin{array}{l}\text { Tidak ada kebocoran } \\
\text { pada saluran irigasi, } \\
\text { bangunan bagi sadap } \\
\begin{array}{l}\text { berfungsi, pintu air } \\
\text { berungsi }\end{array}\end{array}$ \\
\hline
\end{tabular}

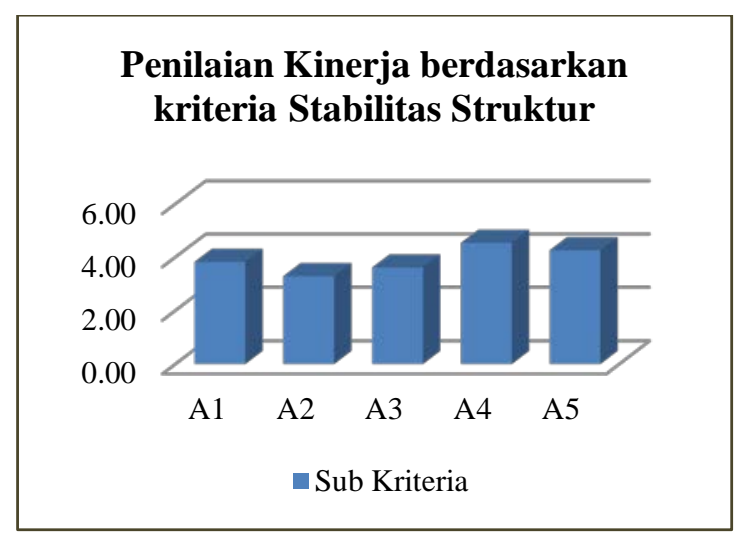

Gambar 2 Penilaian Kinerja Berdasarkan Kriteria Stabilitas Struktur

Selanjutnya berdasarkan kriteria Fisik dan Lingkungan pada Tabel 6, Hasil penilaian menunjukkan bahwa nilai bobot terendah ada pada curah hujan dan evapotranspirasi.
Tabel 6.Penjelasan Kriteria Fisik dan Lingkungan

\begin{tabular}{|c|l|}
\hline $\begin{array}{c}\text { Kriteria Fisik dan } \\
\text { Lingkungan }\end{array}$ & \multicolumn{1}{|c|}{ Pernyataan } \\
\hline $\begin{array}{c}\text { B1. Perubahan } \\
\text { Bentangan } \\
\text { Alam }\end{array}$ & $\begin{array}{l}\text { Tidak terjadi perubahan } \\
\text { bentangan alam yang } \\
\text { mengakibatkan } \\
\text { perubahan aliran air } \\
\text { masuk embung }\end{array}$ \\
\hline $\begin{array}{c}\text { B2. Curah Hujan } \\
\text { dan }\end{array}$ & $\begin{array}{l}\text { Curah hujan yang tinggi } \\
\text { sehingga menjamin } \\
\text { ketersediaan air }\end{array}$ \\
\hline $\begin{array}{c}\text { B3. Struktur Tanah } \\
\text { sekitar Embung }\end{array}$ & Memenuhi Syarat \\
\hline $\begin{array}{c}\text { B4. Tanaman } \\
\text { Pengganggu }\end{array}$ & $\begin{array}{l}\text { Tidak terdapat } \\
\text { tambuhan tinggi pada } \\
\text { tubuh bendungan, dan } \\
\text { pelimpah }\end{array}$ \\
\hline
\end{tabular}

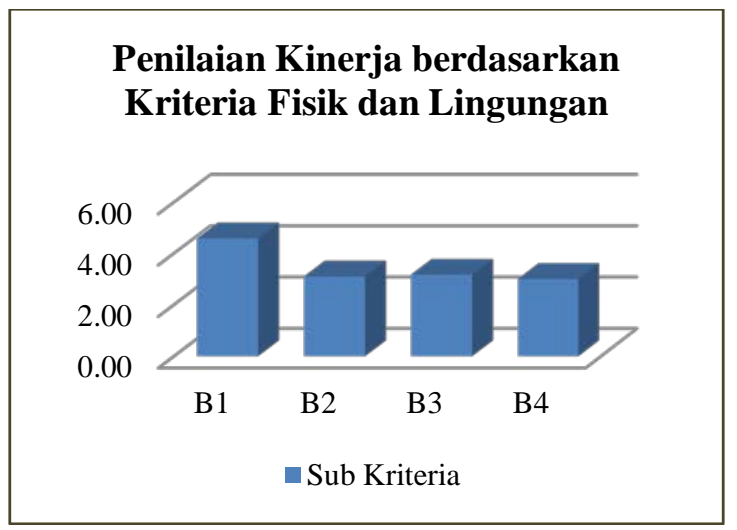

Gambar 3 Penilaian Kinerja berdasarkan kriteria Fisk dan Lingkungan

Pada kriteria Ekonomi (Tabel 7), hasil analisa menunjukkan bahwa berdasarkan kriteria ekonomi, untuk hasil produksi pertanian dan nilai manfaat embung Haliwen dikategorikan baik. Sedangkan dana investasi terlihat masih kurang, sehingga perlu diperkuat lagi dengan lagi dengan dana pemeliharaan agar operasi embung dapat ditingkatkan

Tabel 7 Penjelasan Kriteria Ekonomi

\begin{tabular}{|c|c|}
\hline $\begin{array}{c}\text { Kriteria } \\
\text { Ekonomi/Finansial }\end{array}$ & \multicolumn{1}{|c|}{ Pernyataan } \\
\hline $\begin{array}{c}\text { C1. Hasil Produksi } \\
\text { Pertanian }\end{array}$ & Padi dan Jagung \\
\hline $\begin{array}{c}\text { C2. Nilai manfaat } \\
\text { ekonomi embung }\end{array}$ & Rasio Manfaat Biaya \\
\hline C3. Dana Investasi & $\begin{array}{l}\text { Dana Operasi dan } \\
\text { Pemeliharaan }\end{array}$ \\
\hline
\end{tabular}




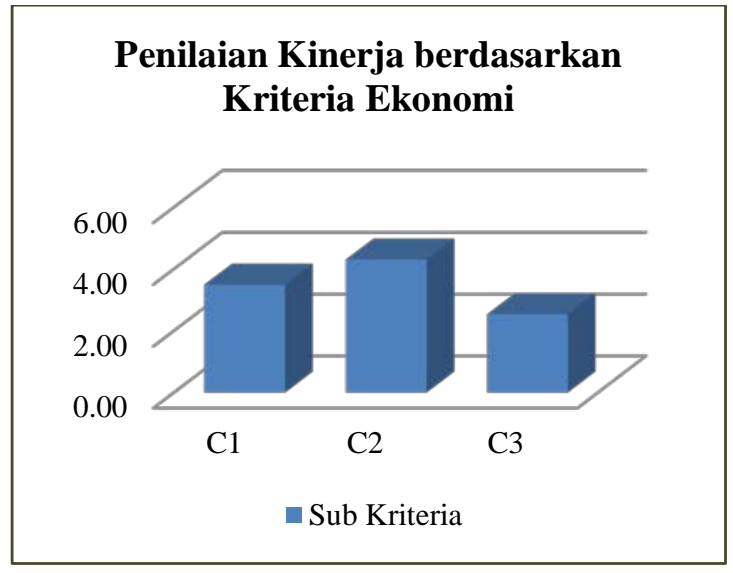

Gambar 4 Penilaian Kinerja berdasarkan kriteria ekonomi

Selanjutnya, pada kriteria Kebijakan Pemerintah aspek yang dinilai adalah rencana tata ruang wilayah, peneydiaan anggaran pemeliharaan, water management dan aspek kelembagaan. Hasil penelitian menunjukkan bahwa pada kriteria kebijakan pemerintah secara umum masih belum kuat mendukung kegiatan operasi dan pemeliharaan. Pada aspek rencana tata ruang wilayah penialian menunjukkan nilai baik yang artinya menurut responden, keberadaan embung telah sesuai dengan RTRW. Sedangkan dari aspek penyediaan anggaran pemeliharaan, water management dan kelembagaan masih sangat lemah, dimana ditunjukkan dengan nilai bobot di bawah 3 .

Tabel 8 Penjelasan Kriteria Kebijakan Pemerintah

\begin{tabular}{|c|l|}
\hline \multicolumn{1}{|c|}{$\begin{array}{c}\text { Kriteria Kebijakan } \\
\text { Pemerintah }\end{array}$} & \multicolumn{1}{|c|}{ Pejelasan } \\
\hline $\begin{array}{c}\text { D1. Rencana Tata Ruang } \\
\text { Wilayah }\end{array}$ & $\begin{array}{l}\text { Kesesuaian dengan } \\
\text { Rencana Tata } \\
\text { Ruang Wilayah }\end{array}$ \\
\hline $\begin{array}{c}\text { D2. Penyediaan } \\
\text { Anggaran } \\
\text { Pemeliharaan }\end{array}$ & $\begin{array}{l}\text { Tersedia Anggaran } \\
\text { Pemeliharaan setiap } \\
\text { tahun }\end{array}$ \\
\hline D3. Water Management & $\begin{array}{l}\text { Terdapat sistem } \\
\text { pembagian air }\end{array}$ \\
\hline $\begin{array}{c}\text { D4. Aspek Kelembagaan } \\
\text { (Organisasi) }\end{array}$ & $\begin{array}{l}\text { P3AI berfungsi } \\
\text { dengan baik }\end{array}$ \\
\hline
\end{tabular}

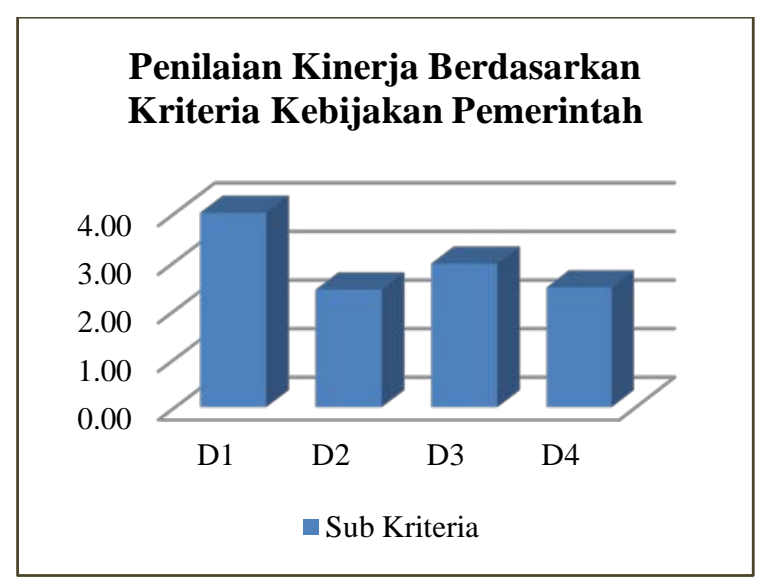

Gambar 5 Penilaian Kinerja berdasarkan kriteria Kebijakan Pemerintah

Penilaian berikut adalah berdasarkan kriteria Sosial Budaya. Hasil penelitian menunjukkan bahwa pada kriteria sosial budaya partisipasi masyarakat masih belum menunjukkan kinerja yang baik (belum optimal) dimana dalam kategori cukup. Sedangkan adanya hukum adat dengan system denda ternyata ikut membantu mempertahanan kinerja embung. Sedangkan dari aspek pengembangan kepariwisataan sangat jauh dari harapan, dengan nilai kurang, menunjukkan belum termanfaatkan sama sekali.

Tabel 9 .Penjelasan Kriteria Sosial Budaya

\begin{tabular}{|c|l|}
\hline Kriteria Sosial Budaya & \multicolumn{1}{|c|}{ Pernyataan } \\
\hline $\begin{array}{c}\text { E1. Partisipasi } \\
\text { Masyarakat }\end{array}$ & $\begin{array}{l}\text { Partisipasi petani } \\
\text { pemakai air aktif }\end{array}$ \\
\hline $\begin{array}{l}\text { E2. Kearifan } \\
\text { Lokal/Hukum Adat }\end{array}$ & $\begin{array}{l}\text { Adanya hukum adat } \\
\text { terkait pemanfaatan } \\
\text { embung }\end{array}$ \\
\hline $\begin{array}{l}\text { E3. Pengembangan } \\
\text { Kepariwisataan }\end{array}$ & $\begin{array}{l}\text { Tersedia fasilitas } \\
\text { wisata di area } \\
\text { embung }\end{array}$ \\
\hline
\end{tabular}




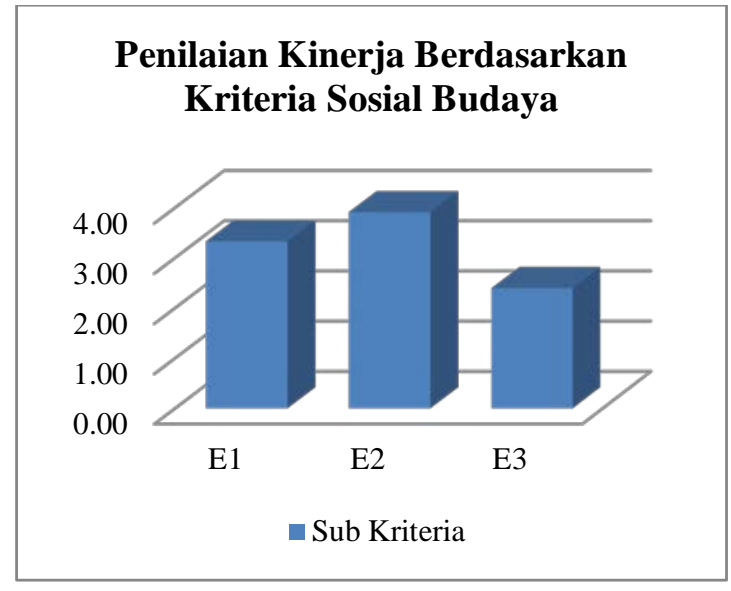

Gambar 6 Penilaian Kinerja berdasarkan kriteria sosial budaya

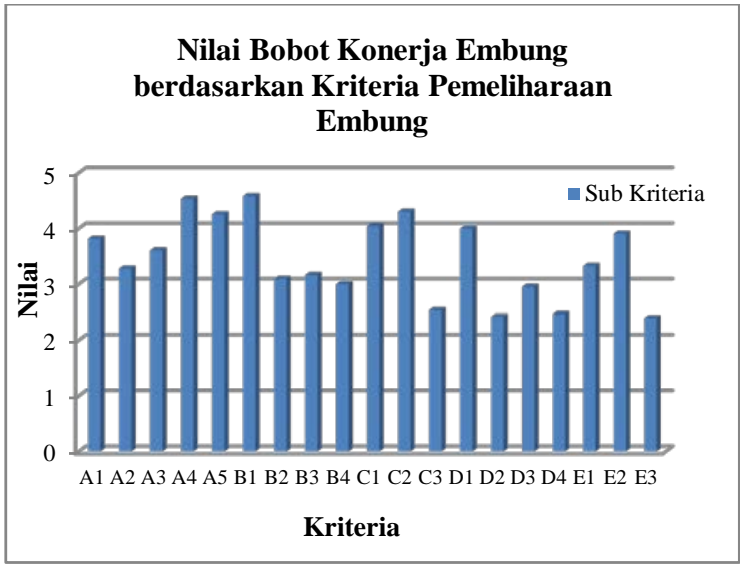

Gambar 7 Distribusi Nilai Bobot Kinerja Berdasarkan Kriteria Pemeliharaan Embung Haliwen.

Dengan demikian dapat ditentukan nilai bobot kinerja embung Haliwen adalah

NK Stabiltas Struktur + NK Fisik + NK Ekonomi + NK Kebijakan Pemerintah + NK Sosbud Jumlah kriteria

$$
\frac{3,898+3,459+3,628+2,459+3,209}{5}=3,41
$$

Jadi rata-rata nilai bobot kinerja embung Haliwen adalah 3,41 berdasarkan kriteria Pemeliharaan Embung Irigasi Haliwen.

\section{KESIMPULAN}

Berdasarkan Pembahasan di atas maka dapat disimpulkan beberapa hal sebagai berikut :

1. Kinerja embung Haliwen berdasarkan Kriteria Pemeliharaan Embung Irigasi adalah sebesar 3,41 yang berarti dalam katagori cukup.

2. Atas dasar nilai bobot dapat dikatakan kegiatan operasi dan pemeliharaan Irigasi Embung Haliwen belum optimal

3. Pada sub kriteria D2 (Penyediaan anggaran pemeliharaan), D3 (water management), E3 (Pengembangan kepariwisataan) memiliki bobot di bawah 3, yang artinya kinerjanya masih kurang.

\section{DAFTAR PUSTAKA}

[1] Anonimous. 2003. "Laporan Pelaksanaan Pkerjaan Perencanaan Teknis Embung Haliwen”. Proyek PPSA Popinsi NTT.

[2] Aditya, R. DS. 2014. USU Institusional Repository, Repository.usu.ac.id.

[3] Bria, M. 2017. "Pengembangan Model Pengambilan Keputusan Prioritas dalam Perencanaan Pemeliharaan Embung Irigasi Berbasis Analisis Multikriteria untuk Menjamin Keberlanjutan Sistem Irigasi di Timor". Laporan Penelitian.

[4] Ernanda, H. 2013. “Kajian Penilaian Kondisi dan Keberfungsian Komponen Aset Berbasis AHP dalam Penetapan Urutan Prioritas Pengelolaan Aset irigasi Bendung Kabupaten Jember". 
[5] Hermantoro. 2011. "Peningkatan Efektifitas Tampungan Embung melalui perbaikan bentuk dan dimensi”. Buletin Geologi Tata Lingkungan (Bulletin of Environmental Geology), Vol. 21 No. 1 April 2011: 35 - 41.

[6] Kasiro, I.. 1994. "Pedoman Kriteria Desain Embung Kecil untuk Daerah Semi Kering di Indonesia”. Direktorat Jenderal Pengairan Departemen Pekerjaan Umum, Jakarta.

[7] Keputusan Menteri Pekerjaan Umum No. 13/PRT/M/2012.

[8] Notoatmojo, B., dkk. 2001. "Optimasi Pengembangan Embung di Indonesia". Journal The WINNERS, Vol. 2 No. 1, Maret 2001: 12-17.

[9] Wiradnyana, I.G.O., dkk. 2013. "Partisipasi Masyarakat Pemakai Air dalam Operasi dan Pemeliharaan Embung di Kabupaten Karangasem". Jurnal Spektran Vol.1, No.1, Januari 2013. 
Melchior Bria dkk, Penilaian Kinerja Embung Haliwen... 